\title{
LEGISLATIVE FRAMEWORK OF BROADCASTING IN ROMANIA AND IN THE EUROPEAN UNION
}

\author{
Diana Magdalena PRIHOANCĂ \\ "Vasile Alecsandri" University of Bacău \\ dianaprihoanca@yahoo.com \\ Brândusa-Mariana AMĂLĂNCEI \\ "Vasile Alecsandri" University of Bacău \\ brandusa_amalancei@yahoo.com
}

\begin{abstract}
Romania's adherence to the European Union implied the previous and entire acceptance of the Community acquis in force on 31st of December 1999. Our country didn't request any period of transition or of derogation in this meaning, being among the first states from East Europe that regulated the audio-visual department, after the occidental model. In order to harmonize the Romanian legislation with the European standards, The National Council of the Audio-Visual Department adopted and transposed a whole range of acts and decisions that we will try to synthesize in our paper. In the adoption of the acquis, the NAC has to watch whether the adopted decisions are conform to the progress at European level. It is necessary to continue strengthening the administrative capacities of NAC to ensure a transparent and predictable implementation of the regulatory framework in the field of audiovisual policy. In Romania, the normative acts that regulate aspects concerning general advertising and promotional communication through television are: Advertising Act and the Broadcasting Act.
\end{abstract}

\section{Keywords}

community acquis; regulations on broadcasting; advertising law; the National Audiovisual Council; transposition of directives

\section{JEL Classification}

M3

The European Union has shown quite a few times that communication plays a vital role in its construction, although it almost always comes back to the problem of living together without belonging to the same culture. However, we consider that this culture represents a true reflection of the personality of each individual, born of enculturation, but also of "acculturation", that is to say, the contact with other cultures. Despite its difficulty, the communication between representatives of different cultures often leads to the emergence of a common reality, the only one able to guarantee the cohesion of multicultural societies. Similarly to these companies, the European Union owes some cohesion to its inhabitants who share a common reality through communication (Dacheux, 1994).

At the institutional level, the development of the communication policy of the Union is a task of the European Commission whose specialized body "General direction of Broadcasting, Information, Communication and Culture" (DG X) puts emphasis on the distinction between information and communication. It was found that the informational policy fails to convince Europeans that from the taken actions benefits the assembly of the Community.

This failure explains the reasons for which the European information was trusted to the media and the Commission had to develop an audiovisual communication. 
The instruments of the audiovisual policy are the adopted documents under Article 151 (4) of the Treaty establishing the European Community (1992). These instruments aim specifically the cultural aspects, that is, to respect and promote the diversity of European cultures.

The weight of the audiovisual becomes even stronger as it corresponds to the use of an "image strategy" and economic policy of the Community. So, the audiovisual sector combines properly and unitarily the cultural, social and economic aspects. Therefore, the starting point of any analysis of policy applicable to broadcasting must be the recognition of the important role played by this sector in our society, but also the need to ensure a balance between the free market and the protection of general interest.

The development of the audiovisual policy of the European Union has two fundamental objectives, which are pursued in taking into account the cultural dimension of the audiovisual sector: (Pascal and Vlad, 2004)

- Establishing and maintaining the activity of a genuine European area for audiovisual services;

- Consolidate the industry of European programs.

The action of the European Union in the audiovisual sector is essentially based on two pillars: a legislative pillar to organize the movement of television broadcasts within the European area (The "Television without Frontiers") and a financial pillar to support the audiovisual sector and designed to facilitate the circulation of European creations (The MEDIA program ${ }^{1}$ ) -two action moods, normative and incentive, to defend European cinematographic and audiovisual creation and the promotion of the use of these works within the Union and outside. The Union has therefore positively influenced, both at management level and development level. The reference instrument for regulation of television in Europe for over fifteen years, the TWF Directive, has contributed to the diversity and growth of this sector, reconciling the cultural and economic objectives. However, the emergence of new audiovisual media services has imposed a redefinition of the European regulatory framework. The newly- proposed directive "Audiovisual Media Services" reflects the need to extend the field of application of present regulations to all audiovisual content services, regardless of technology or distribution platforms used. (www.robertschuman.eu/question_europe.php?num=qe-48\#ancre_25)

To join the European Union, Romania has fully accepted the community acquis in force starting December 31st, 1999 and has not requested any transitional period or a waiver being able to fully practice on the date of its adherence. In fact, Romania was among the first countries in Eastern Europe to adopt a regulation of broadcasting and a modern regulatory body, according to the Western model.

In order to harmonize the Romanian legislation on regulations and standards of the European Union, the National Audiovisual Council (NAC) has adopted and implemented a series of actions and decisions. This board is an autonomous public authority and guarantor of the public interest in the field of audiovisual communication.

\footnotetext{
${ }^{1}$ The MEDIA I(1990-1995) and II(1996-2000), despite the relatively modest means of intervention had a positive balance sheet. The new versions structured around MEDIA Plus and MEDIA Training (20012005, extended until $31^{\text {st }}$ December 2006). MEDIA Plus financially supports actions of development, distribution and promotion, while MEDIA Training aims to strength entraining in the fields of writing, financial and commercial management, and new technologies. MEDIA 2007, a unique program combining the section for the development, distribution and promotion, and those relating to training, began in 2007and will end in 2013.
} 
In its reports, the European Commission noted the progress made by Romania lately regarding Chapter 20: "Audiovisual culture and policy."

As for audiovisual policies, the European Convention on Trans-frontier Television was ratified and its Amending Protocol was signed in February 2003. The regulatory authority in this area, the CNA has continued to adopt decisions in order to practice the Broadcasting Act. Following the adoption of this law in July 2002, the Romanian legislation is largely aligned with the acquis. Amendments of technical order which should be made to the Broadcasting Act specifically target the jurisdiction and limitation of retransmission.

Romania has also continued to strengthen its administrative capacities in the field of broadcasting to ensure the foreseeable, transparent and efficient implementation of the legislative framework related to audiovisual policies.

The ratification of the European Convention on Trans-frontier Television and the adoption of a considerable number of decisions considering the Broadcasting Act represents significant progress made by Romania in the field of audiovisual and mentioned in various country reports.

The continuation of the implementation of the TSF Directive has been possible thanks to the decisions adopted by the CAN, decisions concerning freedom of retransmission, advertising and teleshopping, the right to reply, the promotion of audiovisual creation and delivery of audiovisual license.

Following the adoption of Law no. 504/2002 on broadcasting, the enactment by the Council of Europe of the Act concerning the ratification of the European Convention on Trans-frontier Television and on the Protocol amending the Convention, Romania fulfills the requirements to participate Media Plus Program (2001-2005) - program that encourages the development, distribution and promotion of European works.

This program aims to improve the competitiveness in the European audiovisual industry with a series of measures relating to vocational training, the development of production projects, distribution and promotion of film and audio-visual programs. (www.europa.eu/scadplus/leg/fr/lvb/l24224.htm.)

The position of CNA as an independent authority has also been strengthened by the development of the PHARE Project RO 0107.02 (2002-2004): "The adoption and implementation of the acquis in the audiovisual field - the improving of elaboration of policies and the development of administrative capacities", whose objectives include: developing and implementing a policy of balanced and proportionate audiovisual to ensure free competition and pluralism; increasing the general awareness regarding the adoption and implementation of the acquis; enhanced NAC in developing legislative projects and in the implementation of policies in accordance with harmonized legislative framework of the audiovisual; facilitation for members of Parliament, government and professionals to know and understand the contents of the acquis and standards, guidelines and principles in the European audiovisual; more knowledge among the general public about the consequences of harmonization of the Romanian audiovisual on European standards. (www.cna.ro/IMG/pdf/primul_pr_phare.pdf)

The reports of monitoring and the reports of evaluation confirm that all of these goals have been achieved.

Given the positive progress of Phare RO 0107.02 project co-funded by national grants, which ran from 2002 to 2004, and which referred in particular to provide technical and material support, the NAC was able to conduct a second Phare project PHARE 2004/016-772.03.15.01, from 2007 to 2008, fully funded, this time by European funds. This second project aimed to deepen and broaden skills in the Romanian audiovisual sector. The central objective was to enrich the experience and knowledge of the members of NAC and of the specialized personnel of the Community acquis in the audiovisual sector. The program included an analysis of 
the audiovisual market in Romania in terms of four specific studies: behavior, habits and satisfaction of viewers and listeners, the influence of television on children, the impact of advertising on children and the impact of media on voting behavior of the public. The continuing education courses offered at NAC and proposed to its staff were devoted to the themes of protection of miners, respect for human dignity, public interest, media pluralism and quality of information.

In the same time, there were envisioned internships in IT initiation and English courses. The program included study visits nearby the regulatory authorities of other European states, conferences and workshops. During the project, four information bulletins on the latest international developments in the audiovisual sector have been published. At the end of the program there has been a media campaign for the protection of minors in the audiovisual field.

It was found that between 15 January 2007 and 14 February 2008, all actions in this project were successful.

The framework law in the Romanian audiovisual sector was revised in October 2003. The revision has particularly strengthened the position of NAC which increased the mandate of its members from 4 to 6 years in order to enlarge its political independence but it has also helped to clarify the sanction procedures and to introduce the possibility of more nuanced and proportionate actions.

In 2004, the administrative capacity of NAC has augmented through a training on European legislation and on technical skills of control.

In 2005, Romania has largely aligned its legislation with the community acquis, adopting two amendments still to be made to the audiovisual law concerning the competences and freedom of reception. Nevertheless, the principle of nondiscrimination based on nationality concerning television broadcasting is not respected. This is due to the adoption of a Law on Cinematography which includes an obligation for all Romanian broadcasters to reserve a share of at least $5 \%$ of broadcasting time for Romanian films. (www.europa.eu/scadplus/leg/fr/lvb/ e20108.htm.) Therefore, Romania should complete its alignment, while continuing to strengthen its administrative capacities.

In December 2007, the Commission presented a revision of the "Television without Frontiers", whose main objective is to modernize the existing rules so as to reflect technological and commercial development of the European audiovisual sector. The Directive also aims to alleviate the current regulations, especially with regard to advertising and distinguishes between "linear" (traditional television, Internet, mobile telephony) and "non-linear" (television and information on request).

Invited by the Commission to relax these regulations, states of the European Union have made little progress in adapting their national legislation. The deadline to finalize the implementation of these changes has been established in December 2009. It is estimated having a single market for all audiovisual media services in Europe.

The only one to fully implement the new EU rules on audiovisual was Romania. On 25 November 2008 it adopted a new government decree amending its 2002 law on broadcasting in order to incorporate the measures of the new European directive there. This regulation provides to producers and suppliers of television programs the opportunity to have an easier access to a financing from new forms of audiovisual advertising such as the split screen or product placement, licensed in all programs except newscasts, documentaries and television programs. An easier interruption of diffusion programs will be achieved through the abolition of the rule requiring 20 minutes between advertising breaks. This regulation aims to strengthen the European television sector and the audiovisual one creating fair competition conditions for audiovisual media services "without borders". 
The liberalization options offered by the Directive have been fully exploited by our country especially regarding the placement of products. At the time of the official notification of these changes, the Commission will verify whether the 2007 Directive was fully respected in Romania.

In the adoption of the acquis, the NAC has to watch whether the adopted decisions are conform to the progress at European level. It is necessary to continue strengthening the administrative capacities of NAC to ensure a transparent and predictable implementation of the regulatory framework in the field of audiovisual policy.

In Romania, the normative acts that regulate aspects concerning general advertising and promotional communication through television are: Advertising Act and the Broadcasting Act.

The law no. 148/2000 on advertising, adopted by the Senate of Romania on $29^{\text {th }}$ of June 2000 and published in the Official Gazette no. 359 of 2 August 2000, has as its goal the protection of consumers of goods and of services, but also of producers, traders or persons providing services. The regulations contained in the text of this Act apply to the content of advertising messages regardless of the means of communication. As for advertising broadcast by radio and television, the conditions laid down therein are complemented by the Broadcasting Act.

The Advertising Act contains four chapters. Chapter I contains general provisions concerning radio and television advertising, the definitions of specialty terms, the features of advertising and prohibitions concerning ads. Chapter II deals with misleading and comparative advertising. Chapter III includes special provisions for certain products (tobacco, alcoholic beverages, narcotic and psychotropic substances, weapons, explosives and drugs). Chapter IV outlines the penalties for noncompliance with this law.

The law no. 504/2002 on broadcasting, which transposes into our legislation the prejudices of the "Television without Frontiers", was adopted June $27^{\text {th }}$, 2002, amended and supplemented by Law no. 402 of $7^{\text {th }}$ October 2003 and published in the Official Gazette no. 709 of 10 October 2003. Structured into eight chapters, it defines the specialty terms and the broadcasting quality, regulating on the one hand, the freedom of communication on the Romanian territory of television programs and radio broadcasters who are under the jurisdiction of States members of the European Union, and on the other hand, the right of everyone to freely receive television programs (Chapter 1). The Law regulates also the functioning of the National Audiovisual Council (members, functions, duties, etc. Chapter 2), sets the content of audiovisual communication (regulations regarding the transmission of advertising and teleshopping through interim television, advertising of certain products such as cigarettes, drugs and alcoholic drinks, etc. (Chapter 3) establishes the legal regime of property in the field of broadcasting, but also the fact that the measure of audience and of quotas will be conducted in accordance with standards and to the international use through specialized agencies, designated after an auction (Chapter 4), covers all aspects related to licenses and authorizations of the audiovisual sector - components, time spent, situations where the NAC or the National Regulatory Authority for Communications may revoke the license (Chapter 5), specifies the limits of the right to exclusivity (the last three chapters). Thus, under Article 83, every person has the right to receive information, by audio or audiovisual means, on any issue or event of public interest, the contraventions and penalties for non-compliance of this Act, respectively, transitional and final provisions. The law no. 504/2002 was also completed by Law no. 116 of $\mathbf{1 9}^{\text {th }}$ May 2008, published in Official Gazette no. 384 of $21^{\text {st }}$ May 2008. 
In 2000, the NAC has also adopted a series of decisions on marketing communication via television to align domestic legislation with EU legislation on broadcasting:

- Decision no. 65 of $23^{\text {rd }}$ May 2000 on compulsory standards for advertising, teleshopping and sponsorship in the audiovisual sector;

- Decision no. 21 of $\mathbf{2 8}^{\text {th }}$ January 2003 on advertising and teleshopping for medicines, medical treatments, nutritional supplements; Decision no. 22 of $\mathbf{2 8}^{\text {th }}$ January 2003 dealing with the rules of advertising and teleshopping (political advertising, advertising offices of lawyers and notaries, advertising for alcoholic beverages and food); Decision no. 36 of $13^{\text {th }}$ February 2003 on the schedule of advertising for distilled alcoholic beverages; Decision no. 38 of $\mathbf{1 8}^{\text {th }}$ February 2003 on political advertising and publicity related to exercising certain professions. The content of decisions no. 21, 22, 36 and 38 was subsequently included in the Decision no. 123 of $30^{\text {th }}$ June 2003, amended and supplemented by Decision no. 17 of $5^{\text {th }}$ February 2004 concerning the dissemination of advertising and teleshopping, but also the promotion of medicines;

- Decision no. 187 of $3^{\text {rd }}$ April 2006, the most recent decision by the NAC updated by Decision no. 335/2006, 194/2007, 516/2007, 762/2007, 1105/2007 and 50/2009 and effective from February $3^{\text {rd }}$, 2009, containing the code for content regulation of broadcasting. The seventh title of this decision, Sponsorship, advertising, teleshopping, regulates the advertising for alcohol, food, drugs, political advertising, advertising on exercising certain professions, teleshopping programs. (www.cna.ro/Decizia-nr-nr187-din-3-aprilie.html)

To meet its obligations as a member state of the European Union, reported also to the commitment of Romania as a signatory of the Final Acts of the Regional Radio Communication Conference in Geneva, organized by the International Telecommunication Union (ITU), the Romanian Government adopted in June 2013 the HG 403 - Strategy for transition from terrestrial to digital terrestrial television and implementing digital multimedia services nationwide. This process must be completed by 17 June 2015 and will involve not only technical changes, but will require upgrading audiovisual landscape, bringing introduction of new regulations to ensure efficient use of radio spectrum, achieved by migrating to digital television, and starting information campaigns that will facilitate the understanding of what is required for the transition and subsequent achievement (http://www.cna.ro/HOTRARE-Nr-403-din-19-iunie-2013.html).

During 2012 - 2014, CNA decisions targeted communication activity on electoral market. At the elections held for different structures were adopted following acts:

- Decision no. 586 of July 10, 2012 to reflect on the radio and television the referendum on impeaching the President of Romania

- Decision no. 738 of 1 November 2012 on the principles and rules of election campaign for the Chamber of Deputies and the Senate, through audiovisual media services

- Decision no. 185 of 20 March 2014 on the rules of conduct in audiovisual campaign for the election of Romanian members in the European Parliament

- $\quad$ Decision no. 255 of April 8, 2014 on the principles and rules of conduct in audiovisual partial parliamentary elections.

In conclusion, we can say that the Romanian legislation is largely aligned with the acquis, although some adjustments have to be made on the Law of audiovisual. It is also needed to ensure the alignment with the acquis in all decisions applicable to the law. Romania must also comply with certain legislative and administrative provisions 
laid down in Directive 2010/13/EU of the European Parliament and of the Council of $\mathbf{1 0}^{\text {th }}$ March 2010 concerning the provision of audiovisual media services (Directive "Audiovisual Media Services"). At latest $19^{\text {th }}$ December 2011, and every three years, the Commission shall submit to the European Parliament, the Council and the European Economic and Social Committee a report on the application of this Directive.

\section{References}

Consilul Naţional al Audiovizualului, Fostul Cod audiovizual care a fost în vigoare până la data de 10 martie 2011, available at http://www.cna.ro/Decizia-nr-nr187-din-3-aprilie.html.

Consilul Naţional al Audiovizualului, HOTĂRÂRE Nr. 403 din 19 iunie 2013, available at http://www.cna.ro/HOT-RARE-Nr-403-din-19-iunie-2013.html.

Dacheux, É. (1994), Les stratégies de communication persuasive dans l'Union Européenne, L'Harmattan, Paris.

Europa - Syntheses de la legislation de L'UE, MEDIA Plus (2001-2006): programme d'encouragement au développement, à la distribution et à la promotion des œuvres européennes, available at http://europa.eu/legislation_summaries/ audiovisual_and_media/l24224_fr.htm

Fondation Robert Schuman (2006), La politique audiovisuelle de l'Union européenne, available at www.robertschuman.eu/question_europe.php?num=qe-48\#ancre_25.

Pascal, I., Vlad, M. (2004), Cultura şi politica în domeniul audiovizualului, Centrul de Resurse Juridice, Bucureşti. 